\title{
ரाயm
}

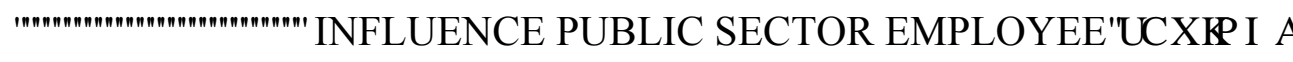

\author{
Robert Clark \\ Olivia S. Mitchell \\ Working Paper 19511 \\ http://www.nber.org/papers/w19511
NATIONAL BUREAU OF ECONOMIC RESEARCH
1050 Massachusetts Avenue
Cambridge, MA 02138 \\ October 2013
}

The research reported herein was performed pursuant to a grant from the Smith Richardson Foundation to the National Bureau of Economic Research; additional research support was provided by the Pension Research Council/Boettner Center at The Wharton School of the University of Pennsylvania. The authors have benefitted from helpful discussions with Jeffrey Brown, Michael Hurd, Joe Newhouse, Joshua Rauh, John Shoven, and Sita Slavov. They greatly appreciate the excellent programming assistance of Yong Yu. Opinions and errors are solely those of the authors and not of the institutions with whom the authors are affiliated. The views expressed herein are those of the authors and do not necessarily reflect the views of the National Bureau of Economic Research.

At least one co-author has disclosed a financial relationship of potential relevance for this research. Further information is available online at http://www.nber.org/papers/w19511.ack

NBER working papers are circulated for discussion and comment purposes. They have not been peerreviewed or been subject to the review by the NBER Board of Directors that accompanies official NBER publications.

(C) 2013 by Robert Clark and Olivia S. Mitchell. All rights reserved. Short sections of text, not to exceed two paragraphs, may be quoted without explicit permission provided that full credit, including (C notice, is given to the source. 
How Does Retiree Health Insurance Influence Public Sector Employee Saving?

Robert Clark and Olivia S. Mitchell

NBER Working Paper No. 19511

October 2013

JEL No. H75,I11,I18,I30

\begin{abstract}
Economic theory predicts that employer-provided retiree health insurance benefits crowd-out household wealth accumulation. Nevertheless, there is little research on the impacts of retiree health insurance on wealth accruals, so this paper utilizes a unique data file on three baseline cohorts from the Health and Retirement Study to explore how employer-provided retiree health insurance may influence net household wealth among public sector employees, where retiree healthcare benefits are still quite prevalent. We find that most full-time public sector employees who anticipate receiving employer-provided health insurance coverage in retirement save less than their private sector uncovered counterparts.
\end{abstract}

\author{
Robert Clark \\ Poole College of Management \\ Box 7229 \\ North Carolina State University \\ Raleigh, NC 27695 \\ and NBER \\ robert_clark@ncsu.edu \\ Olivia S. Mitchell \\ University of Pennsylvania \\ Wharton School \\ 3620 Locust Walk, St 3000 SH-DH \\ Philadelphia, PA 19104-6302 \\ and NBER \\ mitchelo@wharton.upenn.edu
}




\section{How Does Retiree Health Insurance Influence Public Sector Employee Saving?}

In the United States, the cost of health care insurance for retirees can be very steep indeed. For retirees too young for Medicare, estimated annual health insurance premiums easily amount to $\$ 14,000$ per year for a couple. ${ }^{1}$ Even for those age 65 and older who are covered by Medicare, out-of-pocket costs for a median couple can be \$5,300 per year, and at the 90th percentile, annual expenses can total $\$ 110,000$ for a couple. ${ }^{2}$ Accordingly, as workers plan for and look ahead to retirement, they increasingly must recognize that health insurance costs may profoundly affect both their health and their ability to consume other goods and services during their golden years.

Employees who expect that they will be included in employer-provided group retiree health insurance coverage will most likely need to save less during their working careers due to the generosity of this benefit. For this reason, economic theory would predict that employerprovided retiree health insurance (RHI) benefits would be hypothesized to have a crowding-out effect on private household wealth accumulation, not dissimilar to that reported elsewhere for employer pensions, Social Security, and Medicare. ${ }^{3}$ An interesting theoretical question is

\footnotetext{
${ }^{1}$ See McArdle, Stark, Levinson, and Neuman (2012). We also generated similar estimates using online calculators for a hypothetical couple both age 60 for PPO coverage with no deductible and $\$ 20 / \$ 30$ co-payments in the State of Pennsylvania; c.f. http://www.ehealthinsurance.com/ehi/ifp/compare-plans?noSelectedPlan=true.

2 This assumes each spouse incurs the median out of pocket spending of $\$ 2,500 /$ year in 2008 , for a total of $\$ 5,335$ for a couple in 2012. At the $90^{\text {th }}$ percentile, annual expenses would total $\$ 110,000$ for the same couple. See Hoffman and Jackson (2012).

${ }^{3}$ For instance, Gruber and Yelowitz (1999) find a strong negative effect of Medicaid eligibility on wealth. Focusing on elderly households, Levin (1995) reported some evidence for precautionary saving by those having little health insurance, while Starr-McCluer (1996) found only mixed evidence that U.S. households facing greater health risks accumulated more wealth (the latter study did not differentiate active worker coverage from prospective retiree health insurance, however). Guariglia and Rossi (2004) use UK data and discern some crowding-out of
} 
whether this crowding-out should be dollar for dollar or somewhat less. The magnitude of any reductions in retirement saving would be influenced by the extent of the employer subsidy (the proportion of the premium paid by the employer), the expected value of the promised health insurance, whether individual expects to achieve the required years of service to qualify for the benefit, whether the individual expects the employer will honor the promise to provide the insurance, and whether spouses/partners and dependents can be included in the plan.

While numerous studies have previously estimated the impacts of pension and Social Security benefits on household retirement asset accumulation, ${ }^{4}$ we are unaware of any similar research on the impacts of retiree health insurance per se. Accordingly, the present paper explores how employer-provided retiree health insurance may influence net household wealth among public sector employees, where RHI benefits are still quite prevalent.

In the U.S., most private sector U.S. firms no longer offer post-retirement healthcare benefits (Fronstin 2010). By contrast, most public sector employers do continue to offer jobbased health insurance to retired employees (Clark and Morrill 2010). Still, the rising cost of RHI is beginning to challenge state and local governments' ability to continue providing this benefit over time (GAO 2007; Moran 2010). In fact, of late, some public employers have begun to implement RHI plan constraints by, for instance, limiting coverage to workers with long tenure and shifting an increasing proportion of the plan premiums to retirees. Some public employers have also imposed cost-shifting on active and retired workers (Coggburn 2010). These changes are all taking place against the backdrop of national changes in the healthcare

private saving when publicly provided health coverage is of poor quality. Yet none of these studies explicitly focuses on retiree health insurance among public versus private sector employees, as we do here.

${ }^{4}$ For instance Hurd, Michaud, and Rohwedder (2012: 107) use cross-national micro datasets to conclude that "extra dollar of pension wealth depresses accumulated financial assets around the time of retirement by 22 cents." 
environment, particularly with the 2010 passage of the Affordable Care Act (ACA). The law's impacts, as we argue below, will be felt by public sector employers who offer health plans for active as well as retired employees. ${ }^{5}$

Economists and policy analysts have devoted considerable attention to examining the impact of pension plans on individual saving and retirement decisions. Nevertheless, only a handful of studies asks how RHI shapes key lifetime choices influencing retiree wellbeing, to date. The present paper offers the first comprehensive empirical analysis of the impact of retiree health plans of wealth accumulation of public employees. In what follows, we begin with a review of retiree health plans in the public sector. Next, we evaluate how the promise of subsidized retiree health insurance affects the need to save for retirement. As noted, theory suggests that workers covered by retiree health insurance would be likely to save less and retire earlier than comparable workers not covered by this type of retirement plan. Here we focus on the first hypothesis; Shoven and Slavov (2013) have a recent paper addressing the second.

To conduct the empirical analysis, we utilize a unique datafile on three baseline cohorts surveyed in the Health and Retirement Study (HRS). Our general strategy is to first generate household wealth values using the HRS, and then we compare these wealth values across workers covered by retiree health insurance plans versus those of their non-insured counterparts. We control for whether the workers held jobs with Federal, state, or local government employers, or whether they worked for the private sector. A variety of controls is also taken into account as will be detailed below, so as to make the attributes of the employees as similar as possible.

Our key findings may be summarized as follows:

\footnotetext{
${ }^{5}$ For instance Segal (2013:7) states that "[s]ponsors of state employee plans will be able to compare the cost and value of those plan offerings to what the public Exchanges are offering."
} 
- Most full-time public employees anticipate having health plan retiree coverage, unlike many private sector workers;

- Public sector employees covered by retiree health plans had substantially less wealth than similar private sector employees without retiree health insurance. In our data, Federal workers had about $\$ 91,000$ (20\%) less net wealth and $\$ 97,000$ (31\%) less financial wealth than private sector employees lacking RHI; state/local workers with RHI accumulated about $\$ 72,000$ (or $16 \%$ ) less net wealth, and $\$ 77,000$ (or $24 \%$ ) less in financial wealth than their uninsured private sector counterparts.

- After controlling on socioeconomic status and differences in pension coverage, net wealth for Federal employees was \$107,000 less than for workers without RHI, and the state/local difference in net wealth was $\$ 73,000$.

In a final section, we consider how state and local government RHI benefits might respond to the implementation of the Affordable Care Act taking effect January of 2014. We suggest that the introduction of state insurance exchanges and Federal subsidies for low-income retirees may alter the labor market for public sector employees in important ways.

\section{Retiree Health Plans in the Public Sector}

To clarify the role of retiree health insurance in retirement planning, we begin by examining how these plans vary across state, local, and Federal government employers, and over time. Specific plan impacts would be anticipated to depend on plan generosity and the extent of the RHI subsidy provided by the employer.

Most full-time U.S. public sector employees today are covered by health plans that extend benefits to retirees. Yet these plans differ in their generosity and eligibility requirements 
across governmental units (Clark and Morrill 2010). Also in the public sector, the nature of the benefit and its cost may depend on individual worker characteristics. For instance, state or local governments often pay a higher percentage of the RHI premium for longer tenured workers.

In what follows, we briefly review key provisions of retiree health insurance plans for each of the main groups of public sector workers: state employees and teachers, local government workers, and Federal employees. ${ }^{6}$

\section{A. Retiree Health Plans for State Employees and Teachers.}

All states provide health insurance for their full-time active employees, and they also usually offer retired employees the opportunity to participate in some form of state-run health plan for retirees. In some cases, the health plans for general state employees also cover teachers; in other states, there are separate health plans for teachers; and in yet other states, health insurance for teachers is the responsibility of local school districts. ${ }^{7}$

Naturally, how much the RHI plans are worth to retirees depends, in part, on the share of the premiums that employers pick up. An important way in which states differ has to do with how much the RHI plans cost versus the share of the insurance premium paid by the employer on behalf of the retiree. The GAO (2007) reported that, in 2006, 14 states paid the entire RHI premium for retirees who met specific age and service criteria. At the same time, 14 other states offered access only to the state health plans, so retirees had to pay all of the insurance premiums.

Of course, even without an employer subsidy, allowing access only still provides value to retired state employees as they need not be underwritten to gain access to the pool. Additionally,

\footnotetext{
${ }^{6}$ For an examination of military benefits, see http://www.tricare.mil/; we do not cover these in detail here.

${ }^{7}$ Various reports have highlighted the differences in retiree health plans across the states and the unfunded liabilities associated with these plans (Clark and Morrill, 2010; Franzel and Brown 2012, Pew Center on the States, 2010, 2011, 2013).
} 
premiums for public retiree health plans are often determined by blending active workers and retirees in the same risk pool, thereby also offering retirees a subsidy. The remainder of the states pays some portion of the premium, often as a function of years of service and date of employment.

Another key issue is that in recent years, retiree health plan coverage and benefit provisions have been altered, often in response to rising health care costs. In particular, eligibility requirements for coverage and subsidies have changed, along with deductibles, co-payments, plan provisions, and plan premiums. Over time, eligibility requirements for state subsidized RHI have become increasingly restrictive. For example, in 2007, the State of California OPEB Valuation Report noted several changes for retiree health benefits as follows: ${ }^{8}$ retirees with only five years of service and first hired prior to January 1, 1985 were eligible to receive 100 percent of the state's contribution toward the member's health premium upon retirement, but those first hired January 1, 1985 - January 1, 1989 with 10 years of service were eligible for 100 percent of the state's contribution to their premiums. Workers with fewer than 10 years of service received a subsidy equal to years of service times 10 percent. Finally, retirees first hired after January 1, 1989 with fewer than 10 years of service received no subsidy; for those with $10+$ years of service, the state paid 50 percent of the premium and each year over 10 boosted the employer's portion of the premium by an additional five percent of the premium. The State paid 100 percent of the premium for workers with 20 or more years of service. In this way, a California public employee hired prior to 1985 could be eligible for a 100 percent premium subsidy after five years of service, whereas someone hired more recently might be required to have 10 years of

${ }^{8}$ State of California (2011). 
service to receive a 50 percent premium subsidy, and only those with 20 or more years of service would receive the 100 percent subsidy.

Whether workers believe that employers’ RHI promises will be kept is intimately linked to the point that few public sector employers have established substantial trust funds dedicated to pay for retiree health costs (Franzel and Brown 2012, Pew Center on the States 2010, 2011, 2013). Accordingly, some might see these RHI promises as involving a lower level of security than offered by public pension promises, since the latter are somewhat better funded. ${ }^{9}$ Such a concern may be reinforced by the fact that retiree health plans have changed frequently with cost increases sometimes imposed retroactively on retirees. For instance, Clark and Morrill (2010) surveyed several state administrators responsible for retiree health plans who suggested that plan modifications would curtail the fraction of future state retirees eligible to receive retiree health insurance. They also anticipated limiting future state subsidies for RHI premiums. The large unfunded accrued liabilities associated with RHI plans at all levels of government, combined with recent changes in these plans, have no doubt affected public sector workers' views of the likelihood they will recent promised health care benefits. To the extent that benefit security is eroded, this could reduce workers' expectations of promised future health insurance and decrease the effect of coverage on retirement and saving decisions. For all these reasons, the value of retiree health insurance for retirees from the same state with similar years of service can vary depending on employees’ dates of hire.

\section{B. Local Government Retiree Health Plans.}

Little systematic information is available regarding the retiree health insurance plans offered by local governments across the country. The Pew Center on the States (2013) recently

\footnotetext{
${ }^{9}$ Nevertheless, public sector pensions overall are far from fully funded; see for instance NovyMarx and Rauh (2011).
} 
conducted an analysis of 61 cities ranging in population size from New York City to Burlington, Vermont. Collectively, these cities represented 45 percent of all municipal employees, and the study covered 100 local government retiree health plans. The authors found that all cities studied offered retiree health plans, but only a few had accumulated significant assets in a trust fund to prepare for promised future expenditures. Thus, the retiree health plans they examined faced liabilities totaling $\$ 126$ billion for the 61 cities, but the cities had assets of only $\$ 8$ billion backing these promises.

Access to retiree health plans also varies considerably across the local employee workforce: some cities provide access only, while New York City pays 100 percent of the premium for eligible retirees younger than age 65. By contrast, Denver provides a dollar amount subsidy that varies with years of service. The Pew Center on the States (2013) has noted, however, that cities have been modifying retiree health plans rather rapidly of late, in an effort to reduce the growing cost of this benefit. ${ }^{10}$

\section{Health Insurance for Retired Federal Employees.}

The Federal Employees Health Benefits (FEHB) Program has several different plans from which workers and retirees can choose including a Fee-for-Service plan, Preferred Provider Organization, Health Maintenance Organizations, Point of Service, High Deductible Health Plan, and Consumer Driven Health Plan. Accordingly, Federal workers' retiree health insurance will differ from one to another retiree, depending on the health plan elected. Most crucially, benefits do not change as individuals move from active to retired status (U.S. Office of Personnel Management 2013). Federal retirees pay the same premiums and receive the same benefits as

${ }^{10}$ Clark and Morrill (2011) provide a detailed report on the retiree health plans of three cities. 
active Federal employees. Federal retirees are eligible to continue health benefits coverage if they meet the following requirements:

- They are entitled to an immediate annuity under a Federal retirement system for civilian employees; and

- They have been continuously enrolled (or covered as a family member) in any FEHB plan(s) for the five years of service immediately before the date the annuity starts.

Premiums are generally the same for active and retired Federal workers; that is, most retirees share the cost of health insurance premiums with the government in the same way that they did while actively employed. Across the board, government contributions equal the lesser of 72 percent of the overall weighted average, or 75 percent of the total RHI plan premium. Temporary employees do not receive a government contribution toward the cost of their health insurance (U.S. Office of Personnel Management 2013).

\section{Measuring the Value of Retiree Health Insurance.}

It is very difficult to determine an actual value of employer provided health insurance to individual workers. There are several potential methods of assessing the value of such coverage. First, we can look to the market and observe the cost to retirees of various ages of purchasing an individual policy with comparable health insurance. Second, we could attempt to determine the amount of money individuals without employer provided RHI actually spend on health insurance before and after becoming eligible for Medicare. Third, we might assign the per person cost paid by the employer as a value to the employee. While each of these have some merit, we limit our analysis to the first method in an effort to determine a dollar value to the insurance provided to retirees.

Earlier we reported statistics indicating that annual premium for health insurance for a retired individual averaged approximately $\$ 7,000$ per year for a retired individual (see footnotes 
1 and 2). Assuming that a public employee retires at age 58 and purchases health insurance for seven years prior to becoming Medicare-eligible, the present value of fully subsidized insurance, using a 3\% discount rate would be approximately $\$ 43,600$. If the retiree survived for another 20 years after age 65 and if the post-Medicare value of the insurance was $\$ 2,650$ per year, then the present value of this Medigap insurance at age 58 would be an additional $\$ 32,000$. Hence the total value of a lifetime of fully subsidized RHI would be approximately $\$ 75,000$. Obviously, this value depends on the individual's retirement age and life expectancy, as well as the proportion of the premium paid by the employer versus the retiree. The value of RHI to the worker is even greater if retirees are allowed to cover their spouses/partners and dependents. We now examine how the extent of the subsidy varies across public employees.

Our earlier description of public sector retiree health insurance plans in the United States illustrates that it is difficult to accurately measure the value of this benefit to individual public sector employees and retirees. The problem is particularly acute in the state and local public sectors, as plan rules vary considerably across states and local governmental units. In addition, substantial changes have been made to these plans over time, so the value of a RHI promise varies with years of service, age, qualification for a pension benefit, and date of hire. These factors imply that the generosity of RHI to employees of the same governmental unit can be substantially different. Finally, the large unfunded liabilities of state and local RHI plans may raise doubts that these employers will honor these commitments in the long term. Each of these issues indicates the existence of measurement error in the RHI valuation, a point to which we shall return later. For all of these reasons, we concluded that it is impossible using the HRS data to determine the value of RHI to respondents who are nearing retirement and the extent of any employer subsidy to state and local employees. Because of the changing eligibility conditions of 
state plans and general lack of information on the coverage of local employees, the only possible measure of RHI for state and local employees is their own self-reported RHI coverage. It is important to note that the HRS does not include information that would allow us to distinguish state from local employees.

Somewhat less of a measurement problem arises for Federal employees, as all are covered by the same plan which has undergone relatively few changes over time. Accordingly, in the analysis to follow, it is anticipated that the estimated impact of RHI on wealth accumulation will be estimated with more precision for Federal workers, compared to results for employees in the state and local sectors. The two basic requirements for eligibility for Federal RHI are receiving a Federal pension and having five years of coverage in the Federal health plan. Following a similar method used by HRS in valuing pension coverage, we assume that all Federal employees meeting these two eligibility conditions can reasonably expect to be covered by RHI coverage when they retire from Federal employment. Our sample includes only respondents who were employed in the first year they were included in the HRS and who had five years of service with their current employers. It seems reasonable to assume that all fulltime Federal employees are covered by the Federal health plan. Thus, we assign RHI coverage to all full-time Federal employees in our sample who also reported that they were covered by pensions on their current jobs.

\section{How Retiree Health Insurance Can Shape Saving and Retirement Decisions}

A life cycle model of economic behavior predicts that people will strive to smooth utility across time, saving while working so as to enjoy a reasonable lifestyle in retirement. Since higher retiree consumption must be financed by reduced work life consumption, if people behave rationally, their retirement saving plans would be anticipated to take into account anticipated 
retirement income sources. For instance, expected Social Security benefits have been shown to partly offset household retirement saving needs. ${ }^{11}$

Early research ${ }^{12}$ generated a wide range of estimates on the extent of saving reduction per dollar of pension or Social Security wealth using aggregate data. Subsequent analyses using individual survey data did not narrow the estimated effect of retirement benefits on wealth accumulation very much. Thus, Hubbard (1986) found very small offsets (\$0.16 per dollar of pension wealth), while Gale (1998) reported very large offsets (\$0.82 per dollar of pension wealth). Gustman and Steinmeier’s (1999) estimates were around the midpoint (\$0.50 per dollar of pension wealth). There is a related debate over whether tax-favored employer pensions and IRAs increased total national saving or not (c.f., Venti and Wise, 1996; Engen, Gale, and Scholz, 1996), with the bulk of the evidence suggesting that they do have a positive net effect, albeit with some crowd-out.

Similarly, employer pensions and retiree health plans would be thought to directly reduce worker saving needs, given that people anticipate a flow of income or a specified level of health insurance in retirement. Of course, some measurement and statistical complexities arise in the case of RHI that must be explicitly noted. First, and as noted above, the value of retiree health insurance coverage itself is difficult to measure and uncertain over time since employers regularly amend plans via changes in deductibles, co-payments, co-insurance, and premiums. Second, promised benefits from health insurance are less secure than are expected pension benefits due to the lack of pre-funding of RHI benefits. Third, existing datasets have little information on the current value of these benefits, and retiree health values will differ (even for

\footnotetext{
${ }^{11}$ For a recent example of a lifecycle consumption, saving, and portfolio choice model, see Maurer, Mitchell, Rogalla and Kartashov (2013).

12 C.f., Cagan (1965), Katona (1965), Feldstein (1974), Munnell (1974) and Feldstein and Pellechio (1979), among others.
} 
the same employer) depending on when employees are hired and their length of tenure at retirement. Indeed, most of these factors will not actually be measured until employees retire.

When determining the impact of retiree health insurance on saving for retirement, another factor worth noting is the impact that retiree health plans can have on workers' retirement ages. If the existence of the RHI induces workers to retire younger than they would have otherwise, they will then need to save more to finance their retirement consumption over longer periods of time. The jointness of the decision of retirement saving and age of retirement adds complexity to determining how individuals covered by retiree health insurance will adjust their retirement saving. $^{13}$

It is also of note that employers who provide RHI almost always also offer some type of pension plan as well. These pension and health insurance benefits are similar in that they both incorporate incentives affecting firms' ability to attract, retain, and ultimately retire a highquality workforce (Lumsdaine and Mitchell 1999). From the employee's viewpoint, these two benefits would thus jointly affect their private saving patterns and ultimate retirement ages. This means that, when estimating the impact of retiree health coverage on individual retirement saving and retirement, it is important to control for the retirement effects of pension plans as well. Moreover, as French and Jones (2011) note, people having stronger preferences for leisure may select into jobs offering retiree health coverage, and these jobs are also those providing more generous pension coverage. Failure to account for these factors could bias the estimated impact of retiree health coverage on retirement.

\footnotetext{
${ }^{13}$ Shoven and Slavov (2013) examine whether retiree health insurance influences the age of retirement for public employees. Recent studies on impacts of retiree health insurance include Blau and Gilleskie (2001, 2008), Gustman and Steinmeier (1994), French and Jones (2011), Karoly and Rogowski (1994), Robinson and Clark (2010), Madrian (1994), and Nyce et al. (2013).
} 
A final issue worth noting is that uncertainty around medical costs can also influence precautionary saving per se. Kotlikoff's (1988) work suggested that uncertain health expenses had a large positive impact on aggregate saving, whereas actuarially fair health insurance reduced saving. More recently, several authors have argued that uncertain medical expenses play a potentially large role in explaining the saving behavior of older Americans; ${ }^{14}$ French and Jones (2011) concluded that individuals who can self-insure through saving will value retiree health coverage less. Accordingly, RHI can depress personal wealth accrual not only because these benefits represent a source of wealth, but because they reduce older households' exposure to uncertainty and hence curtail the need for precautionary saving.

Based on this analysis, how might workers adjust their retirement saving behavior when their employers offer RHI? First, let us assume that employees believe with certainty that they will reach their expected retirement ages and qualify for RHI, that their employers will honor the promise to provide health insurance in retirement, and that employees value the RHI benefit at least as much as the cost of a comparable privately-purchased health insurance policy. Second, assume that in the absence of the employer-provided RHI, comparable workers would be saving enough to purchase a similar policy in retirement. In such an environment, we could anticipate that workers would reduce their retirement saving approximately dollar-for-dollar, reflecting the value of RHI. Nevertheless, we know from the empirical studies of offsets associated with coverage by defined benefit pension (DB) plans and Social Security that the tradeoff is unlikely to be exact. Moreover, in the HRS dataset, we have no measure of how much employees value the RHI provided, since the survey does not report the degree of employer subsidy for those with this insurance. Accordingly, in what follows, we measure the empirical magnitude of the average

${ }^{14}$ C.f., Love, Palumbo, and Smith (2009), Palumbo (1999), DiNardi, French, and Jones (2010), Hubbard, Skinner, and Zeldes (1994), and Anderson, French, and Lam (2004) 
tradeoff in the data between RHI and wealth accumulations, but we cannot determine whether employees value the insurance as much as what the private market premium would be.

\section{III.Dataset Construction}

To analyze how retiree health insurance is associated with the key outcomes of interest here, we employ three baseline waves from the Health and Retirement Study (HRS). Specifically, we extracted working individuals in the original HRS group (interviewed in 1992), the War Babies (WB) group (2004), and the Early Baby Boomer (EBB) group (2010). We required that all respondents had information on job tenure and their state of residence at baseline, as well as responses to the questions on whether they expected retiree health insurance. Our analysis, below, focuses exclusively on employees with at least five years of employment with their current employer to ensure that these individuals were likely to be eligible for retiree health coverage if such was offered. The size of our analysis sample is 6,650 .

\section{A. HRS Variables}

Several HRS datasets were used to generate the variables used in our analysis. Where possible, we relied on Core HRS variables from the RAND files (St. Clair et al. 2011) supplemented with the relevant raw HRS data files for additional variables. We also obtained permission to use the restricted occupation detail (HRS 2010) identifying which individuals were teachers and local employees at baseline, since most teachers are covered by state-wide retiree pension and medical plans. ${ }^{15}$

\footnotetext{
${ }^{15}$ We also received permission to use the restricted geographic detail records (HRS 2009) for respondents' state of residence at baseline, which we used to infer the portion of premium paid by the employer for state retiree health insurance coverage (from GAO 2007). However we do not report results from this analysis here because the subsidy within a state varies by hire date
} 
Our analytic sample thus included all respondents self-reported as working full or part time at baseline, having job tenure over five years, and for whom we had state of residence information and a response to whether the individual expected to receive retiree health insurance. Only non-proxy interviews are used; the Appendix provides further details on our data construction process.

\section{B. Wealth Variables}

Table 1 summarizes the key variables used in the empirical analysis. Focusing first on the wealth measures of greatest interest here, we incorporate defined contribution (DC) wealth in our measures of total and financial wealth, while we control on DB wealth in the estimating equations. This is because workers tend to have to choose to participate in their DC plans, decide how much to contribute, and how to invest the funds. Accordingly, we incorporate DC balances in the dependent variables measuring net total wealth and net financial wealth. By contrast, employees have little if any direct input into their employers’ DB plans (other than taking a job at a firm with such a plan), and few employees have much understanding of DB benefits (Chan and Stevens 2008). For this reason, the analysis to follow includes employees' defined benefit pension wealth values (if any) in the set of factors accounting for financial and total saving.

\section{Table 1 here}

The specific values of DB and DC wealth used in the present analysis are drawn from Gustman et al. (2010), ${ }^{16}$ and all other asset and debt values are taken from the RAND-cleaned

and tenure, and we could not control for these variables; additionally not all state employees are covered by the same state plan.

${ }^{16}$ The HRS provides, under restricted conditions, data on DC and DB pension wealth generated by and reported in the Gustman et al. (2010) volume. Those authors also explain how the pension wealth data elements were constructed. 
version of the HRS. ${ }^{17}$ Average total net wealth in our sample is approximately $\$ 436,000$ and net financial wealth is $\$ 302,000$ (in 2010\$), values reflective of the relatively older age group under study. Total net wealth includes values reported for checking/saving/money market accounts, stock/bond/mutual fund/investment trusts, as well as the net values of primary/secondary residences, vehicles, business, and IRA/Keogh/DC plan values, minus debt. Total net financial wealth subtracts from net wealth the net values of residences. ${ }^{18}$

Table 2 arrays these two wealth measures according to whether the respondent had retiree health insurance, and whether the respondent was a Federal, state/local, military, private sector, or private (but formerly public sector) employee. Results indicate that, overall, workers with no retiree health insurance accumulated more net wealth and financial wealth than their counterparts without RHI. For instance, Federal workers reported an average net wealth of $\$ 363,400$ compared to $\$ 454,536$ of respondents without RHI implying that Federal employees had about $\$ 91,000$ (20\%) less net wealth and $\$ 97,000$ (31\%) less financial wealth than private sector employees without any retiree health insurance. State/local workers with RHI accumulated about $\$ 72,000$ (or $16 \%$ ) less net wealth, and $\$ 77,000$ (or $24 \%$ ) less in financial wealth, than their uninsured private sector counterparts.

Private sector workers anticipating RHI also saved less, on the order of $\$ 64,000$ (14\%) less in net wealth, and \$53,000 (17\%) less in financial wealth. At least in the aggregate, then, it appears that our hypothesis is supported: workers anticipating receiving RHI did accumulate less wealth than those without such promises. We also tested whether these four groups had

17 Details on the RAND Income and Wealth Imputation Files are provided at http://www.rand.org/labor/aging/dataprod/income-wealth-imputation.html. Our wealth measures are winsorized at the top and bottom $0.5 \%$.

${ }^{18}$ Due to the fact that Social Security wealth has not been computed in a systematic and coherent way for all the HRS waves analyzed here, net and financial wealth includes expected pensions but not Social Security wealth. 
significantly different mean accumulated wealth depending on coverage by RHI. Interestingly, mean wealth for those covered by RHI for Federal, state and local, and private sector employees was significantly lower than mean wealth held by those lacking the promise of employerprovided retiree health insurance. In addition, mean wealth levels for those with RHI across the three public sector employee groups were not significantly different from each other.

Table 2 here

\section{Employment Sector Variables}

To establish whether each worker was employed by a public or private employer, we use HRS questions on employment sector. These questions, however, provided less detail prior to 2006 than afterwards. Before 2006, the HRS asked "Have you ever been employed by a unit of a state, county, or local government?" and “Aside from military service, have you ever been employed by the Federal government?” If the respondent said no to both questions, he was classified as working in the private sector. If the respondent said yes to the first question, a follow-up question was asked: "During what years were you employed?" in that sector. If the individual's years of employment in a state/county/local government included the baseline year, we classified him as working in the state and local sector. If his public sector employment was in the past, we classified him as currently employed in the private sector but having had a past public sector job. From 2006 forward, the HRS asked: "Are you employed by the government at the Federal, state, or local level?” If the respondent answered in the negative, we classified him as a private sector worker. If he answered in the affirmative, a follow-up question was used to distinguish employment sector further "Would that be the Federal, state, or local government?" 
Accordingly we classified individuals as Federal, versus state and local, based on this follow-up question. $^{19}$

In this way, we were able to identify approximately $5 \%$ of our sample as employed by the Federal government, $15 \%$ by state and local governments, $50 \%$ by private sector employers, and $30 \%$ which had worked in the public sector in the past but were currently private sector employees (see Table 1).

\section{Retiree Health Insurance Variable}

The variation in benefit values within and across RHI plans and employees described above makes it difficult to impute a single dollar value to the benefit for respondents in a national survey such as the Health and Retirement Study. Accordingly, we assessed whether a respondent anticipated retiree health insurance (RHI) by relying on the HRS Core questions asked at baseline for state and local employees and our imputation of coverage for Federal employees as described above. Table 1 indicates that $47 \%$ of the sample indicated it anticipated or was receiving employer-provided retiree health insurance.

\section{E. Socioeconomic Controls}

To be able to compare wealth patterns more comprehensively, we hold constant several socioeconomic characteristic controls including the employee's age, marital status, race/ethnicity, sex, educational status, number of children, health status, years on the job, and years worked. Table 1 shows that, in our sample, the average age was about 54, about half were male, $80 \%$ White, and 8\% Hispanic. Around one-fifth had less than a high school education, just under half had completed high school, and almost 30\% had at least some college. The majority, $81 \%$, was married and averaged about three children; some $13 \%$ declared themselves in poor or

\footnotetext{
${ }^{19}$ If the respondent said he was in the military currently, or his years of active service included the baseline year, he was classified as working in the military and excluded from the sample.
} 
fair health, and on average they had worked for 32 years (with 18 years on the current job). Approximately two-thirds of the sample came from the first round HRS, with the remainder representing the War Babies, and Early Baby Boomer cohorts. The empirical specification also includes the respondent's expected retirement age and a cognition measure. ${ }^{20}$ In general, individuals expecting to retire earlier would need to save more for a longer retirement.

\section{Multivariate Regression Results}

Next, we summarize our multivariate results from OLS regression analysis of the two key wealth measures of special interest here. These outcomes are related to the retiree health insurance variables described above, holding constant differences in demographic, income, and pension factors. Our wealth equations control on measures of current annual earnings, years of tenure on the job, and education, all of which are strong proxies for lifetime earnings. We also present results for the entire sample as a whole, and separately for married couples only.

\section{A. Entire Sample}

The first column of coefficient estimates in Table 3 reports on the factors associated with net wealth, whereas the second focuses on financial wealth, for the entire sample.

Table 3 here

The first four rows of the table indicate the differential impact of being a worker with retiree health insurance coverage in each of the sectors, compared to not having RHI, and controlling on other differences across the employee population. The RHI terms remain

\footnotetext{
${ }^{20}$ The respondent's planned retirement age from the RAND file is derived from a variable which asks the respondent about retirement plans, along with another variable asking when the respondent thinks he/she will stop work or retire. The cognition variable we use is also taken from the RAND file, and it refers to the sum of total recall and mental status indices. See St. Claire et al. (2011) and RAND (2011).
} 
economically large and statistically significant for both Federal and state and local employees in both equations. As hypothesized above, the coefficient for Federal government employees is measured quite precisely. The result implies that this group accumulated $\$ 107,408$ less net wealth and \$92,360 less financial wealth compared to employees without RHI, after controlling for other factors. These effects are $118 \%$ and $95 \%$ as large as the differences in means shown in Table 2.

Also, as hypothesized, RHI coverage coefficients for state and local employees are estimated less precisely although still significant at the 10 percent level. These estimates indicate that comparable state and local employees with RHI accumulated about \$72,534 less net wealth. And finally, private sector workers with a RHI promise (including those who held public sector jobs in the past) also are estimated to have saved less but the estimated coefficient is not significantly different from zero.

An interesting additional finding of our analysis is the estimate that higher expected wealth from defined benefit plans is consistent with lower household wealth accumulation. We find that each additional $\$ 1,000$ of DB pension wealth resulted in a reduction of $\$ 178$ in accumulated net wealth and $\$ 164$ of financial wealth. Both coefficients are statistically significant at the $1 \%$ confidence level. These estimates seem sensible in view of the fact that many DB plans are substantially underfunded at present, and so their benefit stream would likely be discounted by participants both due to this risk and due to the fact that they will be paid in years hence.

The other control variables behave as expected, with saving levels significantly higher for Whites (lower for Hispanics), higher for the better paid, better educated, and married, lower for those having many children, and lower for those in poor health. The results also indicate that 
workers planning on retiring later saved significantly less than those anticipating quitting earlier. On average, a respondent expecting to retire one year earlier held additional wealth of $\$ 10,863$. And finally, a respondent having a higher cognition score by a standard deviation above average (i.e., two points above the average of 25) would be expected to have saved about $\$ 10,800$ more.

In sum, we find evidence supportive of the hypothesis that workers covered by retiree health insurance saved less than comparable workers not covered by RHI. Moreover, the group anticipating what is likely the most secure RHI promise - Federal benefits - saved the least.

\section{B. Results for Married Couples}

To investigate the importance of spousal characteristics on household saving, we next restrict the sample to include only respondents who reported being currently married. This is because we cannot allocate jointly-owned assets to one partner or the other. Our analysis sample here now includes the 5,393 married respondents who reported information on their spouses' educational attainment, current working status, RHI coverage, and years of service on current job (if any).

Table 4 reports models for net wealth and net financial wealth for the married sample using a specification that includes all variables used in Table 3 plus the spousal variables described above. Results show that the estimated effects of the respondent's RHI coverage are very similar to those reported previously. Interestingly, the estimated coefficient on the spouse having RHI also indicates that spousal RHI coverage further depresses household wealth accumulation. Estimates of the other variables in the two tables are very similar.

Table 4 here 
In other words, controlling for marital status, spousal human capital, retiree health coverage, work status, and other factors, supports our main conclusion that public sector employees have saved less due to having generous retiree health insurance.

\section{Thoughts on How the ACA Might Affect Our Results}

The recently passed Affordable Care Act is anticipated to change the way many employers think about health insurance benefits. In particular, from January 2014, the ACA will de-link what has long been the primary connection between employment and health insurance for many Americans. While there is considerable controversy about what exactly might happen as a consequence, here we offer some preliminary thoughts focusing particularly on RHI offered to retiring public sector workers.

How employers respond to the ACA in the context of RHI will depend on how job-linked benefits compare to those that might be offered through the Health Exchanges established under the act (Pauly and Duggan 2013). The exchanges will surely make health insurance more accessible to those currently lacking insurance, some of whom are retirees. Moreover, premiums for many workers and retirees will be subsidized on a sliding scale for those with incomes below 400 percent of the Federal Poverty Level (FPL). It has been estimated that the subsidies will cover many individuals, especially those retiring in their 50 s and 60 s. $^{21}$

Accordingly, to the extent that it will become less expensive for some employees to elect ACA-based health insurance than to take up employer-provided RHI, this reduction in the price

\footnotetext{
${ }^{21}$ Premiums for health insurance purchased through the exchanges is to cost no more than two percent of income for incomes up to $133 \%$ of the FPL, and up to $9.5 \%$ of income for those earning $3-400 \%$ of the FPL. These premiums refer to the second lowest-cost offering in the "Silver Plan" category; it is estimated that these plans will cover approximately $70 \%$ of the total cost of medical care.
} 
of retiree health insurance is likely to make some employees and retirees better off. It is also worth noting that wages could rise at firms that drop their RHI benefit offerings (Burtless and Milusheva 2013), passing on cost-savings that employers might experience.

The existence of the exchanges and the Federal subsidy could have implications for our results presented earlier, particularly for workers who retire prior to eligibility for Medicare at age 65. Retirees who were not covered by retiree health on their jobs will now need less wealth in retirement, so the difference in wealth accumulation between those with and without employer-provided RHI would be predicted to decline. Moreover, market-driven wage differentials between those with and without employer-provided RHI would also be predicted to diminish, as a result of the ACA. ${ }^{22}$

\section{Conclusions}

Economic theory predicts that employer-provided group retiree health insurance coverage can reduce employee incentives to save during their working careers. The literature has devoted much attention to measuring crowding-out by pensions, Social Security, Medicare, and national health insurance, little research to date has considered whether rather generous employerprovided retiree health insurance benefits could have the same effect. Our paper offers the first comprehensive empirical analysis of the impact of retiree health plans of wealth accumulation of public employees.

Using HRS data, we show that public sector employees covered by retiree health plans had substantially less wealth than otherwise similar private sector employees lacking retiree

\footnotetext{
${ }^{22}$ It has been suggested that some public sector employers will curtail employees' work hours to avoid having to provide them with benefits (Merline 2013). Unless earnings are raised to compensate for the loss in benefits, this could make it difficult for employers to attract, hire, and retain.
} 
health insurance. In particular, Federal workers had about $\$ 91,000$ (20\%) less net wealth and $\$ 97,000$ (31\%) less financial wealth than private sector employees lacking RHI. We also find that state/local workers with RHI accumulated about $\$ 72,000$ (or 16\%) less net wealth, and $\$ 77,000$ (or $24 \%$ ) less in financial wealth than their uninsured private sector counterparts. After controlling on socioeconomic and pension coverage differences, the Federal employee gap in net wealth was still $118 \%$ as large, and the difference is measured with reasonable statistical precision. For reasons we enumerate above, the state/local workforce wealth differences are measured less robustly, but, after adding controls, it still appears they save $30 \%$ less. 


\section{References}

Anderson, Katharine, Eric French, and Tina Lam. (2004). "You Can’t Take It With You: Asset Run-Down at the End of the Life Cycle.” Economic Perspectives, 28(3), 40-54.

Blau, David M. and Donna B. Gilleskie. (2001). "Retiree Health Insurance and the Labor Force Behavior of Older Men in the 1990s.” Review of Economics and Statistics, 83(1), 64-80.

Blau, David M. and Donna B. Gilleskie. (2008). “The Role of Retiree Health Insurance in the Employment Behavior of Older Men.” International Economic Review, 49(2), 475-514.

Burtless, Gary and Svetlana Milusheva. (2013). "Effects of Employer-Sponsored Health Insurance Costs on Social Security Taxable Wages.” Social Security Bulletin. 73(1): 83108.

Cagan, Phillip. (1965). "The Effect of Pension Plans on Aggregate Saving: Evidence from a Sample Survey.” Occasional Paper 95. New York: Columbia University.

Chan, Sewin and Ann Huff Stevens. (2008). "What You Don't Know Can't Help You: Pension Knowledge and Retirement Decision-Making.” Review of Economics and Statistics. 90 (2): 253-266

Clark, Robert L. and Melinda Sandler Morrill. (2010). Retiree Health Plans in the Public Sector, Northampton, Mass: Edward Elgar Publishing Limited.

Clark, Robert L. and Melinda Sandler Morrill. (2011). "Health Insurance for Active and Retired City Employees: Asheville, Denver, and Oklahoma City” Issue Brief, Center for State and Local Government Excellence, http://slge.org/publications/health-insurance-foractive-and-retired-city-employees-asheville-denver-and-oklahoma-city

Coggburn, Jerrell D. (2010). "How Local Governments are Addressing Retiree Health Care Funding.” Center for State \& Local Government Excellence Issue Brief.

DiNardi, Mariacristina, Eric French, and John Baily Jones (2010). "Why Do the Elderly Save? The Role of Medical Expenses.” Journal of Political Economy, 118(1), 39-75.

Engen, Eric, William Gale, and John Karl Scholz. (1996) “The Illusory Effects of Saving Incentives on Saving,” Journal of Economic Perspectives, 10 (Fall 1996), 113-138.

Feldstein, Martin. (1974). "Social Security, Induced Retirement and Aggregate Capital Accumulation,” Journal of Political Economy 82 (September), 905-926.

Feldstein, Martin and Anthony Pellechio. (1979). "Social Security and Household Wealth Accumulation: New Microeconometric Evidence.” Review of Economics and Statistics 61 (August), 361-68. 
Franzel, Josh and Alexander Brown. (2012). "Understanding Finances and Changes in Retiree Health Care.” Government Finance Review, February, pp. 59-63.

French, Eric and John Bailey Jones. (2011). “The Effects of Health Insurance and Self Insurance on Retirement Behavior.” Econometrica, 79(3), 693-732.

Fronstin, Paul. (2010). “Implications of Health Reform for Retiree Health Benefits.” EBRI Issue Brief. January, \# 338.

Gale, William. (1998). “The Effects of Pensions on Household Wealth: A Reevaluation of Theory and Evidence.” Journal of Political Economy 106 (4) 706-723.

Government Accountability Office (GAO). (2007). State and Local Government Retiree Health Benefits: Current Status of Benefit Structures, Projections, and Fiscal Outlook for Funding Future Costs. Report to the Committee on Finance, US Senate. September. GAO-07-1156. http://www.gao.gov/new.items/d071156.pdf

Gruber, Jonathan and Aaron Yelowitz. (1999). "Public Health Insurance and Private Savings.” Journal of Political Economy. 107(6): 1249-1274.

Guariglia, Alessandra and Mariacristina Rossi. (2004). Journal of Health Economics. 23:761783.

Gustman, Alan L. and Thomas L. Steinmeier. (1994). "Employer Provided Health Insurance and Retirement Behavior.” Industrial and Labor Relations Review, 48(1), 124-140.

Gustman, Alan L. and Thomas L. Steinmeier. (1999). "Effects of Pensions on Savings: Analysis with Data from the Health and Retirement Study." Carnegie-Rochester Conference Series on Public Policy 50, 271-324.

Gustman, Alan L., Thomas L. Steinmeier, and Nahid Tabatabai. (2010). Pensions in the Health and Retirement Study. Cambridge: Harvard University Press.

Health and Retirement Study. (HRS: 2009). Cross-Wave Geographic Information (Detail) Restricted Data 1992-2008. HRS. Institute for Survey Research, University of Michigan.

Health and Retirement Study. (HRS: 2010). Restricted Occupation and Industry Coding in HRS/AHEAD. HRS. Institute for Survey Research, University of Michigan.

Hoffman, Allison and Howell E Jackson. (2012). "Retiree Out-of-Pocket Health Care Spending.” RAND Financial Literacy Working Paper, WR-962-SSA, November.

Hubbard, R. Glenn. (1986). "Pension Wealth and Individual Saving: Some New Evidence,” Journal of Money Credit and Banking 18 (2), 167-178.

Hubbard, R. Glenn, Jonathan Skinner, and Stephen P. Zeldes. (1994). "The Importance of Precautionary Motives in Explaining Individual and Aggregate Saving.” CarnegieRochester Conference Series on Public Policy, 40, 59-125. 
Hurd, Michael, Pierre-Carl Michaud, and Susann Rohwedder. (2012). "The Displacement Effect of Public Pensions on the Accumulation of Financial Assets.” Fiscal Studies. 33(1): 107128.

Karoly, Lynn A. and Jeannette Rogowski. (1994). "The Effect of Access to Post-Retirement Health Insurance on the Decision to Retire Early.” Industrial and Labor Relations Review, 48(1), 103-123.

Katona, George. (1965). Private Pensions and Individual Saving, Ann Arbor: University of Michigan, Survey Research Center.

Kotlikoff, Laurence J. (1988). “Intergenerational Transfers and Savings.” Journal of Economic Perspectives, 2(2), 41-58.

Levin, L. (1995). "Demand for Health Insurance and Precautionary Motives for Saving Among the Elderly.” Journal of Public Economics. 57: 337-367.

Love, David, Michael Palumbo, and Paul Smith. (2009). "The Trajectory of Wealth in Retirement.” Journal of Public Economics, 93(1-2), 191-208.

Lumsdaine, Robin and Olivia S. Mitchell. (1999). "New Developments in the Economics of Retirement”. In Handbook of Labor Economics, eds. Orley Ashenfelter and David Card. Amsterdam: North Holland: 3261-3308.

Madrian, Bridgette C. (1994). “The Effect of Health Insurance on Retirement.” Brookings Papers on Economic Activity, 25(1), 181-232.

Maurer, Raimond, Olivia S. Mitchell, Ralph Rogalla, and Vasily Kartashov. (2013). "Lifecycle Portfolio Choice with Stochastic and Systematic Longevity Risk, and Variable Investment-Linked Deferred Annuities.” Journal of Risk and Insurance. 80(3) Sept.: 649-676.

McArdle, Frank, Ian Stark, Zachary Levinson, and Tricia Neuman. (2012). "How Does the Benefit Value of Medicare Compare to the Benefit Value of Typical Large Employer Plans? A 2012 Update.” Kaiser Family Foundation Issue Brief, April.

Merline, John. (2013). “Local Governments Reeling Under ObamaCare Costs.” Investors' Business Daily. June 19. http://news.investors.com/061913-660419-local-governments-cuthours-to-avoid-obamacare-mandate.htm?p=full

Moran, Jenna Amato. (2010). "The OPEB Tsunami: Riding the Wave of Public Sector Postemployment Health Benefits.” Buffalo Law Review. 58: 677-716.

Munnell, Alicia. (1974). The Effect of Social Security on Personal Saving. Cambridge: Ballinger Press. 
Novy-Marx, Robert, and Joshua Rauh. (2011). "Public Pension Liabilities: How Big Are They and What Are They Worth?” Journal of Finance 66(4): 1207-1245.

Nyce, Steven, Sylvester Schieber, John B. Shoven, Sita Slavov, and David A. Wise. (2013). "Does Retiree Health Insurance Encourage Early Retirement?" Journal of Public Economics. 104, August: 40-51.

Palumbo, Michael G. (1999). "Uncertain Medical Expenses and Precautionary Saving Near the End of the Life Cycle.” The Review of Economic Studies, 66(2): 395-421.

Pauly, Mark and Mark Duggan. (2013). "Employer Insurance under Employer Mandates and Subsidized Exchanges: Time to Dump or Stay?” Health Management, Policy and Innovation. 1 (2): 45-50

Pew Center on the States. 2010. The Trillion Dollar Gap. Pew Center. http://www.pewstates.org/uploadedFiles/PCS_Assets/2010/Trillion_Dollar_Gap_Underfunded_S tate_Retirement_Systems_and_the_Roads_to_Reform.pdf

Pew Center on the States. 2011. The Widening Gap: Updated. Pew Center. http://www.pewstates.org/uploadedFiles/PCS_Assets/2012/Pew_Pensions_Update.pdf

Pew Center on the States. 2013. A Widening Gap in Cities: Short Fall in Pensions and Retiree Health Care. Pew Center. http://www.pewstates.org/uploadedFiles/PCS_Assets/2013/Pew_city_pensions_report.pdf

RAND Corporation. (2011). RAND HRS Data Documentation. Version L, HRS, November.

Robinson, Christina and Robert Clark. (2010). "Retiree Health Insurance and Disengagement from a Career Job.” Journal of Labor Research, 31(3), 247-262.

St. Clair, Patricia, Delia Bugliari, Nancy Campbell, Sandy Chien, Orla Hayden, Michael Hurd, Regan Main, Angela Miu, Mike Moldoff, Constantijn Panis, Philip Pantoja, Afshin Rastegar, Susann Rohwedder, Marian Oshiro, Julie Zissimopoulos. (2011). RAND HRS Data Documentation, Version L. Labor \& Population Program, RAND Center for the Study of Aging.

Segal, Inc. (2013). 2012 Study of State Employee Health Benefits. The Segal Company Survey. Spring.

Shoven, John and Sita Slavov. (2013). "The Role of Retiree Health Insurance in the Early Retirement of State and Local Employees.” Paper presented at Jackson Hole NBER Conference, August 2013.

Starr-McCluer, Martha. (1996). "Health Insurance and Precautionary Savings.” American Economic Review. 86(1): 285-295. 
State of California. (2011). Retiree Health Benefits Program. Actuarial Valuation Report GASB Nos 43 and $45 . \quad$ Viewed June 2011. http://www.sco.ca.gov/FilesEO/CaliforniaGASB45_2011ReportFinal.pdf

U.S. Office of Personnel Management. (viewed June 20, 2013). Federal Employees: Guide Me. http://www.opm.gov/insure/federal_employ/index.asp?ProgramId=1

Venti, Steven and David Wise. (1996). "The Wealth of Cohorts: Retirement Saving and the Changing Assets of Older Americans.” NBER WP 5609. 
Table 1: Variables and Descriptive Statistics in the Analysis Sample

Source: Authors' computations from the HRS; see text. $N=6,650$.

\begin{tabular}{|c|c|c|}
\hline Label & Mean & Std Dev \\
\hline Federal gov't employee & 0.05 & 0.21 \\
\hline $\begin{array}{l}\text { State/Cty/Local gov't } \\
\text { employee }\end{array}$ & 0.15 & 0.36 \\
\hline Private sector employee & 0.50 & 0.50 \\
\hline $\begin{array}{l}\text { Private sector now (public in } \\
\text { past) }\end{array}$ & 0.30 & 0.46 \\
\hline Has retiree health insurance & 0.47 & 0.50 \\
\hline Annual earnings (2012\$) & 56,089 & 55,350 \\
\hline DB pension wealth (2012\$) & 101,354 & 197,079 \\
\hline DC pensionwealth (2012\$) & 44,003 & 178,915 \\
\hline Net Wealth + DC (2012\$) & 436,091 & 709,729 \\
\hline $\begin{array}{l}\text { Net Financial Wealth + DC } \\
(2012 \$)\end{array}$ & 301,556 & 614,569 \\
\hline Age & 54.11 & 4.52 \\
\hline Male & 0.51 & 0.50 \\
\hline White & 0.80 & 0.40 \\
\hline Hispanic & 0.08 & 0.26 \\
\hline LT high school & 0.21 & 0.41 \\
\hline High school & 0.49 & 0.50 \\
\hline Some college & 0.19 & 0.39 \\
\hline Graduate school & 0.11 & 0.31 \\
\hline Married & 0.81 & 0.39 \\
\hline Children number & 2.94 & 1.94 \\
\hline Poor health & 0.13 & 0.33 \\
\hline Years of work & 31.83 & 8.49 \\
\hline Current job tenure & 18.27 & 9.41 \\
\hline Cognition & 24.56 & 4.15 \\
\hline Expected retirement age & 63.22 & 4.10 \\
\hline HRS & 0.70 & 0.46 \\
\hline WB & 0.14 & 0.35 \\
\hline EBB & 0.16 & 0.37 \\
\hline
\end{tabular}


Table 2. Net and Financial Wealth by Employment Sector

Source: Authors' computations from the HRS; see text. (\$2012).

\begin{tabular}{lcccc}
$\begin{array}{l}\text { Nespondent } \\
\text { group }\end{array}$ & $\begin{array}{c}\text { Nealth }+ \\
\text { DC (\$) }\end{array}$ & $\begin{array}{c}\text { Financial } \\
\text { wealth + DC } \\
\text { (\$) }\end{array}$ & \\
\hline No RHI & 454,536 & & 318,114 & \\
RHI Federal & 363,400 & $* * *$ & 220,852 & $* * *$ \\
RHI St/Local & 382,212 & $* * *$ & 240,833 & $* * *$ \\
RHI Private & 390,048 & $* * *$ & 265,614 & $* * *$ \\
RHI Expublic & 485,645 & & 352,606 &
\end{tabular}

Note: * means significantly different compared to No RHI at the $10 \%$; ** 5\%; and *** $1 \%$ level, respectively. Means of RHI Fed, RHI St/Local, and RHI Private are not significantly different from each other (results available on request). 
Table 3. Factors Associated with Net Wealth and Net Financial Wealth, Full Sample Source: Authors' computations from the HRS; see text. (\$2012).

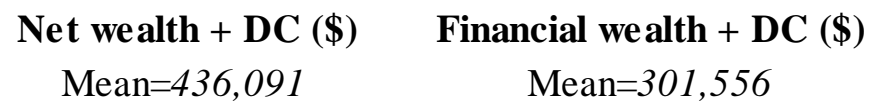

\begin{tabular}{|c|c|c|c|c|c|}
\hline Explanatory Variables & $\underline{\text { Mean }}$ & Estimate & $\underline{\text { St err. }}$ & Estimate & $\underline{\text { St err. }}$ \\
\hline RHI*federal & 0.05 & $-107,408.2$ & $29,510.7 * * *$ & $-92,360.3$ & $24,413.9 * * *$ \\
\hline RHI*stlocal & 0.10 & $-72,533.5$ & $41,971.0 *$ & $-64,279.5$ & $37,059.3 *$ \\
\hline RHI*private & 0.18 & $-7,953.3$ & $22,095.2$ & 4,553.1 & $19,183.3$ \\
\hline RHI*expublic & 0.14 & $37,860.9$ & $33,412.5$ & $42,149.5$ & $30,535.3$ \\
\hline Age & 54.11 & $-8,775.7$ & $18,514.2$ & $-14,826.7$ & $16,576.5$ \\
\hline Age $2 / 10$ & 294.84 & 2,261.4 & $1,809.2$ & 2,493.3 & $1,627.2$ \\
\hline Male & 0.51 & $-52,954.6$ & $17,577.5 * * *$ & $-36,820.5$ & $15,370.9 * *$ \\
\hline White & 0.80 & $100,408.6$ & $16,562.5 * * *$ & $68,172.8$ & $14,558.0 * * *$ \\
\hline Hispanic & 0.08 & $-86,734.9$ & $18,298.8 * * *$ & $-80,456.9$ & $15,037.3 * * *$ \\
\hline LT high school & 0.21 & $-88,947.7$ & $16,861.6 * * *$ & $-64,119.5$ & $14,521.5 * * *$ \\
\hline Some college & 0.19 & $131,802.0$ & $24,778.7 * * *$ & $96,910.3$ & $20,948.7 * * *$ \\
\hline Graduate school & 0.11 & $229,727.0$ & $45,196.2 * * *$ & $195,359.0$ & $41,008.9 * * *$ \\
\hline Married & 0.81 & $215,082.9$ & $17,801.8 * * *$ & $145,163.9$ & $15,760.0 * * *$ \\
\hline Children number & 2.94 & $-20,658.1$ & 4,200.9 *** & $-14,143.8$ & $3,674.4 * * *$ \\
\hline Poorhealth & 0.13 & $-64,133.3$ & $19,350.0 * * *$ & $-50,311.3$ & $16,919.4 * * *$ \\
\hline Years of work & 31.83 & -255.8 & 1,123.1 & -189.6 & 979.5 \\
\hline Work part time & 0.13 & $71,669.1$ & $27,320.1 * * *$ & $51,339.0$ & $23,922.7 * *$ \\
\hline Selfemployed & 0.15 & $402,230.9$ & $40,890.3 * * *$ & $366,069.2$ & $37,080.1 * * *$ \\
\hline Annual earning/1000 (\$) & 56.09 & 4,326.9 & $536.2 * * *$ & 3,538.9 & $410.3^{* * *}$ \\
\hline Stlocal & 0.15 & $16,557.0$ & $39,946.9$ & $15,588.1$ & $35,574.6$ \\
\hline Expublic & 0.30 & $-54,572.5$ & $26,462.9 * *$ & $-32,755.4$ & $23,191.7$ \\
\hline DB wealth/1000 (\$) & 101.35 & -178.2 & $58.4 * * *$ & -163.9 & $51.0 * * *$ \\
\hline Cognition & 24.56 & $5,384.9$ & $1,988.6 * * *$ & $3,665.7$ & $1,720.1 * *$ \\
\hline Expected retirement age & 63.22 & $-10,862.5$ & $2,313.3 * * *$ & $-8,211.8$ & $1,988.2 * * *$ \\
\hline R-squared & & & 0.25 & & 0.22 \\
\hline $\mathrm{N}$ & & & 6,650 & & 6,650 \\
\hline
\end{tabular}

Note: * coefficient significant at the $10 \%$; ** 5\%; and *** $1 \%$ level. Missing value controls for explanatory variables also included. 
Table 4. Factors Associated with Net Wealth and Net Financial Wealth, Married

\begin{tabular}{|c|c|c|c|c|c|}
\hline \multirow[b]{2}{*}{ Explanatory Variables } & \multirow[b]{2}{*}{$\underline{\text { Mean }}$} & \multicolumn{2}{|c|}{ Net we alth + DC (\$) } & \multicolumn{2}{|c|}{ Financial we alth + DC (\$) } \\
\hline & & Estimate & $\underline{\text { St err. }}$ & Estimate & $\underline{\text { St err. }}$ \\
\hline RHI*federal & 0.05 & $-120,697.6$ & $35,035.6 * * *$ & $-106,977.6$ & $28,893.2 * * *$ \\
\hline RHI*stlocal & 0.09 & $-77,683.3$ & $48,817.1$ & $-67,967.7$ & $42,936.5$ \\
\hline RHI*private & 0.17 & $-8,482.5$ & $28,012.2$ & $5,654.8$ & $24,307.5$ \\
\hline RHI*expublic & 0.15 & $30,574.1$ & $38,101.4$ & 39,982.2 & $34,801.2$ \\
\hline Age & 53.92 & $-18,354.0$ & $19,571.7$ & $-21,238.5$ & $17,550.2$ \\
\hline Age2/10 & 293.07 & 3,171.5 & $1,930.5$ & 3,106.5 & $1,739.2 *$ \\
\hline Male & 0.55 & $-58,085.8$ & $20,316.7 * * *$ & $-47,107.1$ & $17,911.3 * * *$ \\
\hline White & 0.83 & $102,989.3$ & $21,315.7 * * *$ & $69,761.3$ & $18,788.6 * * *$ \\
\hline Hispanic & 0.08 & $-50,199.7$ & $21,919.7 * *$ & $-54,935.8$ & $18,274.6 * * *$ \\
\hline LT high school & 0.20 & $-63,625.2$ & $18,638.0 * * *$ & $-45,555.6$ & $16,030.8 * * *$ \\
\hline Some college & 0.19 & $102,553.4$ & $27,469.8 * * *$ & $75,163.3$ & $23,303.7 * * *$ \\
\hline Graduate school & 0.11 & $172,598.6$ & $44,317.8 * * *$ & $158,615.4$ & $40,211.8 * * *$ \\
\hline Children number & 3.12 & $-19,826.2$ & 4,922.6 *** & $-13,085.9$ & 4,320.9*** \\
\hline Poorhealth & 0.12 & $-79,462.8$ & $23,240.5 * * *$ & $-65,855.4$ & $20,231.7 * * *$ \\
\hline Years of work & 31.91 & 115.5 & $1,362.8$ & 101.9 & $1,195.2$ \\
\hline Work part time & 0.13 & $84,466.2$ & $31,895.6 * * *$ & $59,617.7$ & $27,970.7 * *$ \\
\hline Selfemployed & 0.16 & $446,679.4$ & $46,829.6 * * *$ & $406,857.9$ & $42,430.8 * * *$ \\
\hline Annual earning/1000 (\$) & 58.16 & 4,391.6 & $581.9 * * *$ & 3,595.2 & $445.9 * * *$ \\
\hline Stlocal & 0.15 & 3,339.7 & $45,189.2$ & $7,393.2$ & $39,871.1$ \\
\hline Expublic & 0.31 & $-53,501.7$ & $30,178.6 *$ & $-32,314.7$ & $26,488.7$ \\
\hline DB wealth/1000 (\$) & 102.10 & -271.8 & $73.1 * * *$ & -240.4 & $64.2 * * *$ \\
\hline Cognition & 24.67 & $5,053.2$ & $2,411.1 * *$ & $3,525.5$ & $2,098.1 *$ \\
\hline Expected retirement age & 63.11 & $-8,834.6$ & $2,623.8 * * *$ & $-6,393.0$ & $2,242.5 * * *$ \\
\hline Spouse LT high school & 0.21 & $-83,842.1$ & $17,315.5 * * *$ & $-62,936.6$ & $14,988.9 * * *$ \\
\hline Spouse some college & 0.17 & $85,699.0$ & $28,917.6 * * *$ & $56,707.0$ & $24,638.8 * *$ \\
\hline Spouse graduate school & 0.09 & $201,055.4$ & $47,091.3 * * *$ & $156,876.4$ & $42,394.4 * * *$ \\
\hline Spouse working for pay & 0.72 & $-57,459.7$ & $24,162.9 * *$ & $-36,521.5$ & $21,513.7 *$ \\
\hline Spouse RHI & 0.05 & $-18,382.7$ & $29,780.2$ & $-47,968.5$ & $23,106.9 * *$ \\
\hline Spouse current job tenure & 9.83 & $7,047.8$ & $1,130.1 * * *$ & $5,248.8$ & $962.1 * * *$ \\
\hline R-squared & & & 0.26 & & 0.24 \\
\hline $\mathrm{N}$ & & & 5,393 & & 5,393 \\
\hline
\end{tabular}

Note: * coefficient significant at the $10 \%$; ** 5\%; and *** $1 \%$ level. Missing value controls for explanatory variables also included. 


\section{Data Appendix: Construction of the HRS Analysis Sample}

Note: Military employees are dropped from the analysis sample due to the small number of observations.

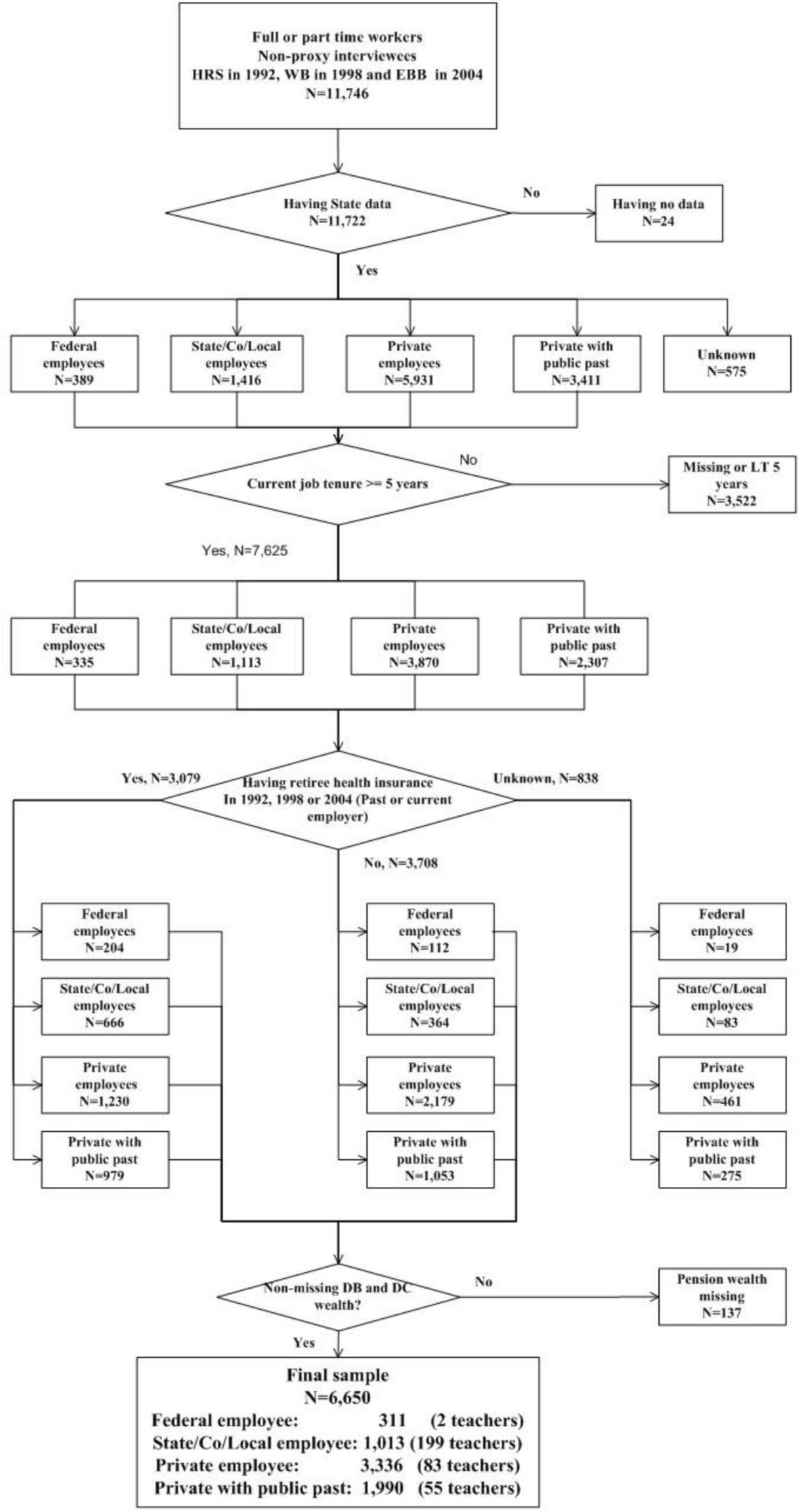




\section{Data Appendix (continued): Variables and Sources}

Label

Federal government

employee

\begin{tabular}{|c|c|c|}
\hline & rfederal & if f3992 = 1 and (f3994 >= \\
\hline & & 1998 or f3996 >= 1998) \\
\hline & rfederal & $\begin{array}{l}\text { rfederal }=1 \text { if } j 1082=1 \text { and } \\
(j 1084>=2004 \text { or jl086 >= } \\
2004)\end{array}$ \\
\hline State/County/Local & rstate & if v3940 = 1 and (v3942 >= \\
\hline government employee & & 1992 or v3944 >= 1992) \\
\hline & rstate & if f3987 = 1 and (f3989 >= \\
\hline & & 1998 and f3991 >= 1998) \\
\hline & rstate & if $\mathrm{j} 1077=1$ and $(\mathrm{jl} 079>=$ \\
\hline & & 2004 or jl081 >= 2004) \\
\hline Private employee & rprivate & $\begin{array}{l}\text { if v3945 = } 5 \text { and v3940 = } 5 \\
\text { and v222 = } 5\end{array}$ \\
\hline & rprivate & $\begin{array}{l}\text { if } \mathrm{f} 3992=5 \text { and } \mathrm{f} 3987=5 \\
\text { and } \mathrm{f} 1008=5\end{array}$ \\
\hline & rprivate & $\begin{array}{l}\text { if jl082 = } 5 \text { and } j 1077=5 \text { and } \\
\text { jb035 = } 5\end{array}$ \\
\hline Private with public past & rexpublic & $\begin{array}{l}\text { if } v 3945=1 \text { or } v 3940=1 \text { or } \\
\text { v222 }=1\end{array}$ \\
\hline & rexpublic & $\begin{array}{l}\text { if } \mathrm{f} 3992=1 \text { or } \mathrm{f} 3987=1 \text { or } \\
\mathrm{f} 1008=1\end{array}$ \\
\hline & rexpublic & $\begin{array}{l}\text { if } \mathrm{j} 1082=1 \text { or } \mathrm{jl} 077=1 \text { and } \\
\text { jb035 = } 1\end{array}$ \\
\hline Retiree health & retiree_health & At baseline: retiree_health $=1$ \\
\hline insurance & & if R1COVRT = 1 and \\
\hline & & R1COVR = 1 or if \\
\hline & & R4COVRT = 1 and \\
\hline & & $\mathrm{R} 4 \mathrm{COVR}=1$ or R7COVRT \\
\hline & & $=1$ and R7COVR = 1 or if \\
\hline & & rfederal=1 and work_ft=1; \\
\hline & & retiree_health $=0$ (if \\
\hline & & R1COVRT $=0$ or R1COVR \\
\hline & & $=0$ ) or (if R4COVRT $=0$ or \\
\hline & & R4COVR $=0$ ) or (if \\
\hline & & $\begin{array}{l}\text { R7COVRT }=0 \text { or R7COVR } \\
=0 \text { ); }\end{array}$ \\
\hline
\end{tabular}

Var. Name Construction

rfederal

if v3945 = 1 and (v3947 >=

1992 or v3949 $>=1992)$

rfederal $=1$ if $j 1082=1$ and

(j1084 $>=2004$ or j1086 >=

1992 or v3944 $>=1992$

if $3987=1$ and

if $\mathrm{j} 1077=1$ and (j1079 >=

2004 or $\mathrm{j} 1081>=2004)$

and $\mathrm{v} 222=5$

if $\mathrm{f} 3992=5$ and $\mathrm{f} 3987=5$

$=5$ and

if $\mathrm{v} 3945=1$ or $\mathrm{v} 3940=1$ or

$\mathrm{v} 222=1$

$\mathrm{f} 1008=1$

if $\mathrm{jl082}=1$ or jl077 = 1 and

b035 = 1

if R1COVRT = 1 and

R4COVR = 1 or R7COVRT

$=1$ and R7COVR $=1$ or if

-1 and work_ft=1;

(if 
(continued)

\begin{tabular}{|c|c|c|}
\hline Respondent DB wealth & income_amt & $\begin{array}{l}\text { At baseline: } \\
\text { income_amt=r1iearn, r4iearn } \\
\text { or r7iearn,. } \\
\text { rdbwealth=sum(cur_dbwlth*, } \\
\text { uprv_dbwlth*) }\end{array}$ \\
\hline Respondent DC wealth & rdcwealth & $\begin{array}{l}\text { sum(cur_dcwlth*, } \\
\text { uprv_dcwlth*) }\end{array}$ \\
\hline $\begin{array}{l}\text { Capped Total Wealth } \\
\text { (Including Secondary } \\
\text { Residence, not including } \\
\text { pension and SSB } \\
\text { wealth) }\end{array}$ & atotb & $\begin{array}{l}\text { atotb=H8ATOTB, winsorized } \\
\text { with top and bottom } 0.5 \%\end{array}$ \\
\hline $\begin{array}{l}\text { Capped Total Financial } \\
\text { Wealth }\end{array}$ & atotf & $\begin{array}{l}\text { atotf }=\mathrm{H}^{*} \text { ATOTN, winsorized } \\
\text { with top and bottom } 0.5 \%\end{array}$ \\
\hline Age & age & age=baseline year - rabyear \\
\hline Male & male & $\begin{array}{l}\text { If ragender }=1 \text { then male }=1 \text {, If } \\
\text { ragender }=2 \text { then male }=0\end{array}$ \\
\hline White & white & $\begin{array}{l}\text { If RARACEM = } 1 \text { then } \\
\text { white }=1 \text {, else }=0\end{array}$ \\
\hline Hispanic & hispanic & $\begin{array}{l}\text { If RAHISPAN=1 then } \\
\text { hispanic=1, else } 0 \text {; }\end{array}$ \\
\hline LT high school & education_lths & $\begin{array}{l}\text { if raedegrm in }(0,1) \text { then } \\
\text { education_lths }=1\end{array}$ \\
\hline High school & education_hs & $\begin{array}{l}\text { if raedegrm in }(2,3) \\
\text { then education_hs }=1\end{array}$ \\
\hline Some college & education_smcl & $\begin{array}{l}\text { if raedegrm in }(4,5) \\
\text { then education_smcl = } 1\end{array}$ \\
\hline Graduate school & education_gtcl & $\begin{array}{l}\text { if raedegrm in }(6,7) \\
\text { then education_gtcl = } 1\end{array}$ \\
\hline Married & married & $\begin{array}{l}\text { At baseline: if r1mstat or } \\
\text { r4mstat or r4mstat in }(1,2,3) \\
\text { then married = } 1 \text {; else } 0\end{array}$ \\
\hline Children number & childnum & $\begin{array}{l}\text { At baseline: childnum = } \\
\text { h1child, h4child or h7child }\end{array}$ \\
\hline Poor health & poorhealth & $\begin{array}{l}\text { At baseline: poorhealth = } 1 \text { if } \\
\text { R1SHLT, R4SHLT or } \\
\text { R7SHLT in }(4,5) \text {, else } 0\end{array}$ \\
\hline
\end{tabular}




\begin{tabular}{|c|c|c|}
\hline Worked year & worked_yr & $\begin{array}{l}\text { At baseline: r1jyears, r4jyears } \\
\text { or r7jyears }\end{array}$ \\
\hline Current job tenure & jobtenureyr & $\begin{array}{l}\text { At baseline: R1JCTEN, } \\
\text { R4JCTEN or R7JCTEN }\end{array}$ \\
\hline Cognition score & cogscore & $\begin{array}{l}\text { cogscore }=\mathrm{r}^{*} \text { cogtot; } \\
\text { cogscore }=\text { mean(nonmissing } \\
\mathrm{r}^{*} \text { cogtot) if missing }\end{array}$ \\
\hline $\begin{array}{l}\text { Expected retirement } \\
\text { year }\end{array}$ & rplanretireage & $\begin{array}{l}\text { rplanretireage= } \mathrm{R} * \mathrm{RPLNYR} \text { - } \\
\text { RABYEAR, if } \mathrm{R} * \mathrm{RPLNYR} \\
\text { missing, use } \mathrm{R} * \mathrm{RPLNYA} ; \\
\text { rplanretireage=mean(nonmissing } \\
\text { value) if missing }\end{array}$ \\
\hline Cohort & $\begin{array}{l}\text { cohort_hrs } \\
\text { cohort_wb } \\
\text { cohort_ebb }\end{array}$ & $\begin{array}{l}\text { cohort_hrs }=1 \text { if hacohort=3 } \\
\text { cohort_wb=1 if hacohort=4 } \\
\text { cohort_ebb=1 if hacohort }=5\end{array}$ \\
\hline
\end{tabular}

Source: Authors' analysis. 